\title{
Laboratory markers has many valuable parameters in the discrimination between acute appendicitis and renal colic
}

\author{
Ethem Acar, M.D., ${ }^{1}$ Önder Özcan, M.D., ${ }^{2}$ Hasan Deliktaş, M.D., ${ }^{3}$ Halil Beydilli, M.D., ${ }^{1}$ İsmail Kırlı, M.D., ${ }^{4}$ \\ Ömer Doğan Alataş, M.D., ${ }^{1}$ Cem Şahin, M.D., ${ }^{4}$ Birdal Yıldırım, M.D., ${ }^{1}$ Ahmet Korkut Belli, M.D. ${ }^{2}$
}

\author{
${ }^{1}$ Department of Emergency Medicine, Muğla Sıtkı Koçman University Faculty of Medicine, Muğla, Turkey \\ ${ }^{2}$ Department of General Surgery, Muğla Sıtkı Koçman University Faculty of Medicine, Muğla, Turkey \\ ${ }^{3}$ Department of Urology, Muğla Sıtkı Koçman University Faculty of Medicine, Muğla, Turkey \\ ${ }^{4}$ Department of Internal Medicine, Muğla Sıtkı Koçman University Faculty of Medicine, Muğla, Turkey
}

\begin{abstract}
BACKGROUND: Only one diagnostic parameter is not available for acute appendicitis. For the establishment of diagnosis, combination of medical history, clinical, laboratory tests, and radiological imaging modalities are used so as to decrease the rates of negative laparotomy and morbidity secondary to delay in diagnosis. Thepresent study aimed to determine haematological and inflammatory markers which will be used in the discrimination of acute appendicitis (AA) and renal colic which are the most frequent and indistinguishable causes of abdominal pain in patients applying to the emergency service.
\end{abstract}

METHODS: A total of 215 patients who presented with abdominal pain and who were histopathologically diagnosed as AA, and 200 patients who presented with abdominal pain and who were diagnosed as renal colic were included into the study. Control group consisted of $6 \mathrm{I}$ patients without any complaints who came to the outpatient clinics of internal medicine only for blood counts. Analyzed blood samples were WBC, RDW, Hb, MCV, MPV, neutrophil, lymphocyte, NLR and PLR. All differences associated with a chance probability of.05 or less were considered statistically significant.

RESULTS: A statistically significant intergroup difference was seen between AA and renal colic groups as for age, WBC, Hb, MCV, neutrophil, lymphocyte, NLR and PLR. A statistically significant intergroup difference was seen between AA and control groups regarding age, WBC, Hb, RDW, MPV, neutrophil, lymphocyte, NLR and PLR. A statistically significant intergroup difference was seen between renal colic and control groups as for age, WBC, RDW, MPV, neutrophil and NLR. In ROC curve analysis, the area under AUCs for WBC, neutrophil, NLR and PLR were $0.896,0.916,0.888$ and 0.725 , respectively $(p \leq 0.05)$.

CONCLUSION: In the discrimination between patients with renal colic and those without any illness, WBC, RDW, MPV, neutrophil and NLR; in the differentiation between the patients with AA and healthy individuals, WBC, RDW, MPV, neutrophil, lymphocyte, NLR and PLR; and more importantly in the discrimination between patients with AA and those with renal colic who presented to emergency services with abdominal pain WBC, neutrophil, lymphocyte, PLR and NLR can be useful parameters.

Keywords: Acute appendicitis; neutrophil/lymphocyte ratio; renal colic.

\section{INTRODUCTION}

Acute abdominal pain is one of the frequent causes of referrals to emergency services and as is known, it consists nearly

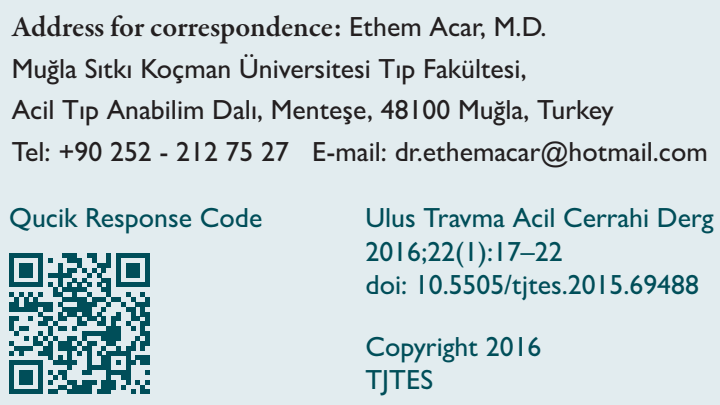

$10 \%$ of all admissions to emergency services. ${ }^{[I]}$ In the year 2004, Turkish Statistical Institute reported that abdominal pain comprised nearly $5 \%$ of all hospitalizations and $30 \%$ of the patients with abdominal pain were undiagnosed. ${ }^{[2]} \mathrm{Not}$ all patients who consulted to the emergency services with abdominal pain require surgical treatment. It is extremely important for the emergency service physician to identify the patients who require surgical intervention and shorten the time elapsed for surgical treatment from the perspectives of professional healthcare and juridical responsibility and the patient.

Acute appendicitis (AA) is one of the most frequent causes of acute abdominal pain, and at the same time, it is an important indication for surgery and complication rates increase as the 
time to surgery increases. ${ }^{[3]}$ Only one diagnostic parameter is not available for acute appendicitis. For the establishment of diagnosis, combination of medical history, clinical, laboratory tests, radiological imaging modalities are used so as to decrease the rates of negative laparotomy and morbidity secondary to delay in diagnosis. However, renal colic is a condition characterized by severe abdominal and flank pain secondary to urinary obstruction due to stone disease. ${ }^{[4]}$ Especially, right ureteral stones can be confused with $A A$, emergency service physician may hesitate between $A A$ requiring require surgery and renal colic that does not require surgery, and the patient can be discharged. Frequently, the patients are subject to further tests. In cases where differential diagnosis is challenging, an experienced ultrasonographer cannot be always accessible. ${ }^{[5]}$ Non-contrasted and/or contrast-enhanced abdominopelvic tomography (CT) requires a specialist for its interpretation, not mentioning exposure to the risks of radiation and contrast agent hypersensitivity. This condition can leave the patient and the physicians in a difficult dilemma. At this point, in addition to physical examination findings and patient's complaints, which are subjective data, objective and easily accessible data derived from analysis of parameters will greatly facilitate the approach of emergency service physician to the patient.

With this study, it was aimed to determine haematological and inflammatory markers which will be used in the discrimination of these two conditions in patients who applied to the emergency service with abdominal pain in consideration of $\mathrm{AA}$ and renal colic which are the most frequent and indistinguishable causes of abdominal pain involving the common mechanistic background of inflammation.

\section{MATERIALS AND METHODS}

\section{Study Design}

This retrospective study was approved by the local Institutional Review Board. Medical files of the patients who consulted to the emergency service with complaints of abdominal pain between November 2013 and November 2014 in our university were reviewed.

A total of two hundred and fifteen patients who presented with abdominal pain and diagnosed as AA which was confirmed by histopathological analysis of the mass excised during surgery were included in one study group. In addition, two hundred patients who consulted to our emergency service with the same complaints and diagnosed as renal colic consisted the other study group. The control group consisted of sixty-five patients without any complaints who came to the outpatient clinics of internal medicine only for blood counts.

Patients' age, gender and whole blood counts at admission recorded in the medical files were analysed. Patients with urinary tract infection or active infection in another region of the body which we thought might effect the analyses of the cases, anaemic patients, patients with chronic renal failure or haematological disease were excluded from the study.

\section{Laboratory Methods}

Blood test results of the patients at their first admissions to the emergency service of our hospital were reviewed. During the study period, blood samples were drawn into tubes containing sodium citrate and analyzed under room temperature in the laboratory of biochemistry using Pentra DF

Table I. The average values of the case

\begin{tabular}{|c|c|c|c|c|}
\hline & $\begin{array}{l}\text { Apandisit } \\
(n=215)\end{array}$ & $\begin{array}{c}\text { Renal Colic } \\
(n=200)\end{array}$ & $\begin{array}{c}\text { Total } \\
(n=415)\end{array}$ & $\mathbf{p}$ \\
\hline & Mean \pm SD & Mean \pm SD & Mean \pm SD & \\
\hline AGE & $28.28 \pm 1.1$ & $39.19 \pm 1.1$ & $33.25 \pm 16.39$ & $=0.000$ \\
\hline White blood cell (4.5-II.0 I03/uL) & $13.3 \pm 2.8$ & $8.05 \pm 1.6$ & $10.24 \pm 4.2$ & $=0.000$ \\
\hline Hemoglobin $(13.5-16 \mathrm{~g} / \mathrm{dL})$ & $13.42 \pm 0.90$ & $13.87 \pm 0.09$ & $13.66 \pm 1.4$ & $=0.001$ \\
\hline Mean corpuscular volume (80-100 fL) & $90.51 \pm 3.7$ & $88.75 \pm 0.49$ & $89.25 \pm 36.77$ & $=0.001$ \\
\hline Red blood cell width (II.8-14.3\%) & $15.25 \pm 0.1$ & $15.17 \pm 0.1$ & $15.10 \pm 1.67$ & $=0.459$ \\
\hline Platelet (I56-373 I03/uL) & $273.69 \pm 4.83$ & $263.53 \pm 43.97$ & $269.58 \pm 64.92$ & $=0.580$ \\
\hline Mean platelet volume (6.9-10.8fL) & $8.98 \pm 0.06$ & $9.93 \pm 0.6$ & $9.33 \pm 5.62$ & $=0.358$ \\
\hline Plateletcrit (19-44\%) & $0.24 \pm 0.0045$ & $0.24 \pm 0.003$ & $0.24 \pm 0.06$ & $=0.788$ \\
\hline Platelet distribution width $(9.0-14.0 \mathrm{fL})$ & $16.02 \pm 0.18$ & $16.32 \pm 0.18$ & $16.17 \pm 2.64$ & $=0.332$ \\
\hline Neutrophil $(2-12 \mathrm{~K} / \mathrm{mL})$ & $10.60 \pm 0.27$ & $4.96 \pm 0.16$ & $7.35 \pm 4.28$ & $=0.000$ \\
\hline Lymphocyte (I-4.9 K/mL) & $1.56 \pm 0.48$ & $2.22 \pm 0.07$ & $1.92 \pm 0.89$ & $=0.000$ \\
\hline Neutrophil/lymphocyte ratio & $8.48 \pm 0.39$ & $3.01 \pm 0.19$ & $5.32 \pm 5.18$ & $=0.000$ \\
\hline Platelet/lymphocyte ratio & $208.62 \pm 7.07$ & $148.73 \pm 7.09$ & $173.37 \pm 10 \mid .58$ & $=0.000$ \\
\hline
\end{tabular}


Nexus, Hariba Medical device. These blood samples were analyzed regarding white blood cell counts (WBC) $(4.5-11.0$ $\left.10^{3} / \mathrm{uL}\right)$, hemoglobin $(\mathrm{Hb})(13.5-16 \mathrm{~g} / \mathrm{dL})$, neutrophil count (Neutrophil) (2-12 K/mL), lymphocyte count (lymphocyte) ( I-4.9 K/mL), mean corpuscular volume (MCV) (80-100 $\mathrm{fL})$, mean corpuscular hemoglobin $(\mathrm{MCH})$ (26-345 pg), red blood cell width (RDW) (I I.8-14.3\%), mean platelet volume (MPV) (6.9-10.8 fL), platelet (plt) (156-373 103/uL), plateletcrit (PCT) (19-44\%) and platelet distribution width (PDW) (9.0-|4.0 fl), neutrophil/lymphocyte ratio (NLR) and platelet/ lymphocyte ratio (PLR).

\section{Statistical Analysis}

Data were analysed using the Statistical Package for Social Sciences 20.0 for Windows (SPSS Inc., Chicago, IL). A nor- mal distribution of the quantitative data was checked using Kolmogorov-Smirnov test. Parametric tests (Independentsamples t-test and posthoc Tukey test) were applied to the data of normal distribution, and non-parametric tests (Mann-Whiney U-test and Kruskal-Wallis Test) were applied to the data of questionably normal distribution. Continuous data were presented as mean \pm standard deviation or median (minimum-maximum), as appropriate. All differences associated with a chance probability of .05 or less were considered statistically significant. Different predictive models were compared by receiver operating characteristic-area under curve (ROC-AUC) statistics.

\section{RESULTS}

Mean age of a total of four hundred and eighty patients was

Table 2. The average of hematological markers of acute appendicitis and control group

\begin{tabular}{|c|c|c|c|}
\hline & Apandisit $(n=215)$ & Control $(n=61)$ & $\mathbf{p}$ \\
\hline & Mean \pm SD & Mean $\pm S D$ & \\
\hline AGE & $28.28 \pm 1.1$ & $31.6 \pm 12.7$ & $=0.018$ \\
\hline White blood cell (4.5-II.0 I03/uL) & $13.3 \pm 2.8$ & $6.8 \pm 1.5$ & $=000$ \\
\hline Hemoglobin (13.5-16 g/dL) & $13.42 \pm 0.90$ & $13.8 \pm 1.3$ & $=0.038$ \\
\hline Red blood cell width (11.8-14.3\%) & $15.25 \pm 0.1$ & $14.3 \pm 1.5$ & $=0.000$ \\
\hline Mean platelet volume (6.9-10.8fL) & $8.98 \pm 0.06$ & $8.6 \pm 0.7$ & $=0.008$ \\
\hline Neutrophil $(2-12 \mathrm{~K} / \mathrm{mL})$ & $10.60 \pm 0.27$ & $3.9 \pm 1.3$ & $=0.000$ \\
\hline lymphocyte (I-4.9 K/mL) & $1.56 \pm 0.48$ & $2.2 \pm 0.5$ & $=0.000$ \\
\hline Neutrophil/lymphocyte ratio & $8.48 \pm 0.39$ & $1.9 \pm 0.9$ & $=0.000$ \\
\hline Platelet/lymphocyte ratio & $208.62 \pm 7.07$ & $132.5 \pm 46.9$ & $=0.000$ \\
\hline Mean corpuscular volume $(80-100 \mathrm{fL})$ & $90.5 I \pm 3.7$ & $86.5 \pm 10.2$ & $=0.222$ \\
\hline Platelet (I56-373 I03/uL) & $273.69 \pm 4.83$ & $274.5 \pm 68.8$ & $=0.496$ \\
\hline
\end{tabular}

Table 3. The average of hematological markers of renal colic and control group

\begin{tabular}{|c|c|c|c|}
\hline & Renal Colic $(n=200)$ & Control $(n=61)$ & $\mathbf{p}$ \\
\hline & Mean $\pm S D$ & Mean $\pm S D$ & \\
\hline AGE & $39.19 \pm 1.1$ & $31.6 \pm 12.7$ & $=0.000$ \\
\hline White blood cell (4.5-II.0 103/uL) & $8.05 \pm 1.6$ & $6.8 \pm 1.5$ & $=0.000$ \\
\hline Red blood cell width (II.8-14.3\%) & $15.17 \pm 0.1$ & $14.3 \pm 1.5$ & $=0.00 \mathrm{I}$ \\
\hline Mean platelet volume $(6.9-10.8 \mathrm{fL})$ & $9.93 \pm 0.6$ & $8.6 \pm 0.7$ & $=0.000$ \\
\hline Neutrophil $(2-12 \mathrm{~K} / \mathrm{mL})$ & $4.96 \pm 0.16$ & $3.9 \pm 1.3$ & $=0.002$ \\
\hline Neutrophil/lymphocyte ratio & $4.96 \pm 0.16$ & $1.9 \pm 0.9$ & $=0.048$ \\
\hline Memoglobin (13.5-16 g/dL) & $13.87 \pm 0.09$ & $13.8 \pm 1.3$ & $=0.800$ \\
\hline Mean corpuscular volume $(80-100 \mathrm{fL})$ & $88.75 \pm 0.49$ & $86.5 \pm 10.2$ & $=0.329$ \\
\hline Platelet (I56-373 103/uL) & $263.53 \pm 43.97$ & $274.5 \pm 68.8$ & $=0.330$ \\
\hline Lymphocyte $(\mathrm{I}-4.9 \mathrm{~K} / \mathrm{mL})$ & $2.22 \pm 0.07$ & $2.2 \pm 0.5$ & $=0.721$ \\
\hline Platelet/lymphocyte ratio & $148.73 \pm 7.09$ & $132.5 \pm 46.9$ & $=0.96 \mathrm{I}$ \\
\hline
\end{tabular}


Table 4. ROC curve analysis of cases

\begin{tabular}{lccccc}
\hline Test Result Variable(s) & Area & Std. Error ${ }^{\mathrm{a}}$ & Asymptotic Sig. ${ }^{b}$ & & \begin{tabular}{c} 
Asymptotic 95\% Confidence Interval \\
\cline { 4 - 6 }
\end{tabular} \\
& & & & Lower Bound & Upper Bound \\
\hline White blood cell & .896 & .014 & .000 & .868 & .823 \\
Neutrophil & .916 & .013 & .000 & .892 & .941 \\
Neutrophil/lymphocyte ratio & .888 & .015 & .000 & .678 \\
Platelet/lymphocyte ratio & .725 & .023 & .000 & .679 \\
\hline
\end{tabular}

Table 5. According to the ROC curve analysis, specifite and sensitive values

\begin{tabular}{lccc}
\hline & Cut-off & Sensitivity (\%) & Specificity (\%) \\
\hline White blood cell & 9850 & 80.5 & 84.2 \\
Neutrophil & 7050 & 80.9 & 85.3 \\
Neutrophil/lymphocyte ratio & 3.3022 & 88.4 & 80 \\
Platelet/lymphocyte ratio & 147.3437 & 70.2 & 67.2 \\
\hline
\end{tabular}

$31.6 \pm 12.7$ years. Our patient population consisted of two hundred and twenty-three (46.5\%) female and two hundred and fifty-seven (53.5\%) male patients. Mean values of hematological markers are given in Table I.

A statistically significant intergroup difference was seen between $A A(n=2 \mid 5)$ and renal colic $(n=200)$ groups as for age, WBC, Hb, MCV, neutrophil, lymphocyte, NLR and PLR $(p \leq 0.05)$ (Table I). A statistically significant intergroup difference was seen between $A A(n=215)$ and control $(n=6 I)$

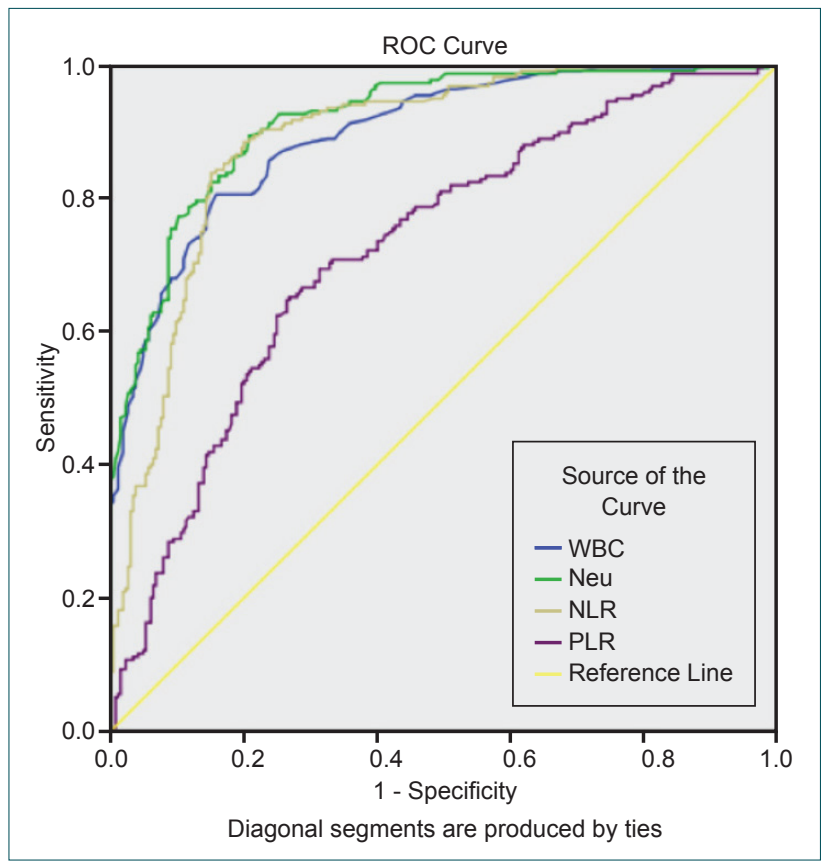

Figure 1. ROC Curves of WBC, Neutrophyl, NLR and PLR (respectively). groups regarding age, WBC, Hb, RDW, MPV, neutrophil, lymphocyte, NLR and PLR (Table 2). A statistically significant intergroup difference was seen between renal colic $(n=200)$ and control $(n=6 I)$ groups as for age, WBC, RDW, MPV, neutrophil and NLR ( $\leq \leq 0.05)$ (Table 3$)$.

In ROC curve analysis, the area under AUCs for WBC, neutrophil, NLR and PLR were 0.896, 0.916, 0.888 and 0.725, respectively $(p \leq 0.05)$ (Table 4, Figure I). Cut-off value of 9850 for WBC had $84.2 \%$ specificity and $80.5 \%$ while cut-off value of 3.3 for NLR had $80 \%$ specificity and $88.4 \%$ sensitivity. In Table 5, specificity and sensitivity values for PLR and neutrophil are shown in Table 5.

\section{DISCUSSION}

With this study, it was found that in the discrimination between patients with renal colic and healthy individuals WBC, RDW, MPV, neutrophil and NLR; and in the differentiation between the patients with AA and healthy individuals, WBC, RDW, MPV, neutrophil, lymphocyte, NLR and PLR; and more importantly, in the discrimination between patients with AA and those with renal colic who presented to emergency services with abdominal pain WBC, neutrophil, lymphocyte, PLR and NLR could be useful parameters in suspected patients.

$\mathrm{AA}$ and renal colic are the most frequent causes of abdominal pain. Emergency service physicians encounter patients with abdominal pain many times a day and try to differentiate between these diagnoses. Tan and et al. ${ }^{[5]}$ have stated that abdominal CT is especially important for suspected cases for diagnosis in their study. They have found that patients undergoing $\mathrm{CT}$ evaluation have a negative appendectomy rate of $5.7 \%$ compared to $17.9 \%$ in those without CT 
evaluation in suspected cases. Emergency service physicians will have difficulties especially in Emergency services without access to sophisticated diagnostic methods such as US and abdominal $\mathrm{CT}^{\left[{ }^{[6]}\right.}$ Particularly, right ureteral stones and $\mathrm{AA}$ are frequently confused, and in the absence of radiological facilities, the physician tries to protect him/herself from consequences of not fulfilling legal and medical responsibilities by means of sole physical examinations Starting from this point, the importance of making differential diagnosis between AA and renal colic, which are frequent causes of abdominal pain, using objective data is already evident. WBC, RDW, MPV, neutrophil and NLR are known to indicate an inflammatory process. Inflammatory markers have been tested in many studies and their diagnostic value is increasing day by day. ${ }^{[7,8]} A A$ is an inflammation of appendix vermiformis which is directly associated with inflammatory processes. Therefore, many inflammatory markers have been studied in AA and are still being studied. As reported in many studies, these inflammatory markers have guided many unexperienced physicians and surgeons in their decision-making processes for surgery. [9] Tanrikulu et al. have compared AA patients with the control group and indicated statistically significantly higher WBC, MPV and RDW values and neutrophil ratios in AA. ${ }^{[3]}$ Still as a conclusion of the same study, they have stated that in suspect cases, MPV and RDW are important parameters, which almost suggest the diagnosis of AA and larger-scale population studies should be conducted on this issue. Albayrak et al. ${ }^{[10]}$ Have performed a study on two hundred and twenty-six patients with AA and expressed that MPVs are lower (7.6 $\mathrm{fl})$ in patients with $A A$ and indicated that MPV might be a guiding marker in the management of AA. In some studies, because of their association with inflammation, WBC counts should be used as a marker in the differential diagnosis of AA. ${ }^{[1-13]}$ Kahramanca et al. ${ }^{[6]}$ Have studied NLR in their research consisting of one thousand and sixty-two cases and expressed that cut-off value of 4.68 for NLR is significant in the establishment of diagnosis of AA, while a cut-off value of 5.74 for NLR yields important clues in the discrimination between complicated and uncomplicated cases with AA. In our study, we compared AA and the control group and in compliance with literature findings, we detected significant changes in WBC, RDW, MPV, neutrophil, PLR and NLR. As the most important outcome of this study, we think that these inflammatory markers can be used in the differential diagnosis between AA and renal colic.

During the acute phase of the renal colic, intraluminal pressure increases due to ureteral obstruction, which induces renal colic pain. During the acute phase, inflammation is not manifested, while during advanced stages via mediators as prostaglandin and nitric oxide inflammation involves pathophysiologic mechanism. ${ }^{[14]}$ In two differently designed study series of one hundred and fifty-six patients where cases with renal colic and stones larger than $10 \mathrm{~mm}$ and WBC values have been studied and evaluated without taking size and pres- ence of stones into consideration, the authors have indicated that WBC and neutrophil counts are significantly higher in cases with renal colic secondary to urolithiasis. ${ }^{[15]}$ During our literature screening, we did not encounter any study, which investigated the association between renal colic and RDW, MPV, NLR and PLR. As an outcome of our study, we found statistically significantly higher WBC and neutrophil counts in patients with renal colic when compared with the control group. In addition to these markers, we also detected significantly higher levels of MCV, RDW and NLR in renal colic. This study is important because it is the first study on this issue. During our literature review, we did not encounter any study, which investigated markers to be used in the differential diagnosis between AA and renal colic patients. Our study is also the first investigation on this issue and we think that it can provide objective and helpful hints to the physicians in terms of the outcomes of the study.

In conclusion, despite medical examination, sometimes we may not diagnose or discriminate between $A A$ and renal colic. We think that, with the patients who present to the emergency service with abdominal pain and could not be differentially-diagnosed with AA or renal colic, WBC, neutrophil, lymphocyte, PLR and NLR can be useful parameters for differential diagnosis of $A A$ and renal colic.

\section{Limitation}

This was a file screening study which tried to determine an inflammatory marker. Essentially, as the most important marker of inflammation, CRP was not observably tested in file screening studies. If CRP had been tested, the inflammatory process could have been more clearly revealed. This deficiency is the limitation of our study.

\section{Conflict of interest: None declared.}

\section{REFERENCES}

1. van Randen A, Laméris W, van Es HW, van Heesewijk HP, van Ramshorst B, Ten Hove W, et al. A comparison of the accuracy of ultrasound and computed tomography in common diagnoses causing acute abdominal pain. Eur Radiol 2011;21:1535-45.

2. Emet M, Eroğlu M, Aslan Ş, Öztürk G. Approach to Patient with Abdominal Pain. EAJM 2007;39:136-41.

3. Tanrikulu CS, Tanrikulu Y, Sabuncuoglu MZ, Karamercan MA, Akkapulu N, Coskun F. Mean platelet volume and red cell distribution width as a diagnostic marker in acute appendicitis. Iran Red Crescent Med J 2014;16:e10211.

4. Duran L, Acar E, Çelenk Y, Karaca A, Yavuz Y. Evaluation of Patients Presenting with Renal Colic in Emergency. Kocatepe Medical Journal 2014;15:274-8.

5. Tan WJ, Pek W, Kabir T, Goh YC, Chan WH, Wong WK, et al. Alvarado score: a guide to computed tomography utilization in appendicitis. ANZ J Surg 2013;83:748-52.

6. Kahramanca S, Ozgehan G, Seker D, Gökce EI, Seker G, Tunç G, et al. Neutrophil-to-lymphocyte ratio as a predictor of acute appendicitis. Ulus 
Travma Acil Cerrahi Derg 2014;20:19-22.

7. Peng W, Li C, Wen TF, Yan LN, Li B, Wang WT, et al. Neutrophil to lymphocyte ratio changes predict small hepatocellular carcinoma survival. J Surg Res 2014;192:402-8.

8. Bhat T, Teli S, Rijal J, Bhat H, Raza M, Khoueiry G, et al. Neutrophil to lymphocyte ratio and cardiovascular diseases: a review. Expert Rev Cardiovasc Ther 2013;11:55,9.

9. Chung $\mathrm{CH}, \mathrm{Ng} \mathrm{CP}$, Lai KK. Delays by patients, emergency physicians, and surgeons in the management of acute appendicitis: retrospective study. Hong Kong Med J 2000;6:254-9.

10. Albayrak Y, Albayrak A, Albayrak F, Yildirim R, Aylu B, Uyanik A, et al. Mean platelet volume: a new predictor in confirming acute appendicitis diagnosis. Clinical and applied thrombosis/hemostasis: official journal of the International Academy of Clinical and Applied Thrombosis/Hemo- stasis 2011;17:362-6.

11. Andersson RE. Meta-analysis of the clinical and laboratory diagnosis of appendicitis. Br J Surg 2004;91:28-37.

12. Birchley D. Patients with clinical acute appendicitis should have pre-operative full blood count and C-reactive protein assays. Ann R Coll Surg Engl 2006;88:27-32.

13. Narci H, Turk E, Karagulle E, Togan T, Karabulut K. The role of mean platelet volume in the diagnosis of acute appendicitis: a retrospective case-controlled study. Iran Red Crescent Med J 2013;15:e11934.

14. Müslümanoğlu AY, Tepeler A. Renal colic, Diagnosis and treatment. Marmara Medical Journal 2008;21:187-92.

15. Sfoungaristos S, Kavouras A, Katafigiotis I, Perimenis P. Role of white blood cell and neutrophil counts in predicting spontaneous stone passage in patients with renal colic. BJU Int 2012;110(8 Pt B):E339-45.

\title{
ORIJINAL ÇALIŞMA - ÖZET
}

\section{Akut apandisit ve renal kolik ayırımında çok değerli laboratuvar markırları vardır \\ Dr. Ethem Acar, ${ }^{1}$ Dr. Önder Özcan, ${ }^{2}$ Dr. Hasan Deliktaş, ${ }^{3}$ Dr. Halil Beydilli, ${ }^{1}$ Dr. İsmail Kırlı, ${ }^{4}$ \\ Dr. Ömer Doğan Alataş, ${ }^{1}$ Dr. Cem Şahin, ${ }^{4}$ Dr. Birdal Yıldırım, ${ }^{1}$ Dr. Ahmet Korkut Belli ${ }^{2}$}

\author{
${ }^{1}$ Muğla Sıtkı Koçman Üniversitesi Tıp Fakültesi, Acil Tıp Anabilim Dalı, Muğla \\ ${ }^{2}$ Muğla Sıtkı Koçman Üniversitesi Tıp Fakültesi, Genel Cerrahi Anabilim Dalı, Muğla \\ ${ }^{3}$ Muğla Sıtkı Koçman Üniversitesi Tıp Fakültesi, Üroloji Anabilim Dalı, Muğla
}

${ }^{4}$ Muğla Sıtkı Koçman Üniversitesi Tıp Fakültesi, İç Hastalıkları Anabilim Dalı, Muğla

AMAÇ: Akut apandisitte tek başına tanı koydurucu bir parametre yoktur. Tanıda anamnez, klinik, laboratuvar testleri, radyolojik görüntüleme yöntemleri bir arada kullanılarak negatif laparatomi oranını azaltmak ve tanıda gecikme nedeniyle morbidite oranını artırmamak hedeflenmektedir. Ayıııı tanıları ekarte etmek bu amaca yardımcı olmaktadır. Biz bu çalışmayla karın ağrısının en sık sebepleri olan apandist ve renal koliğin ayırımında kullanılacak inflamatuvar markerları değerlendirerek ayıııı tanıda bize sağlayabileceği katkıları irdelemeyi amaçladık.

GEREÇ VE YÖNTEM: Çalışmamızda karın ağrısı şikayeti ile gelmiş ve incelemeleri sonucu akut apandisit ön tanısı konularak ameliyata alınan ve patolojik tanısı da akut apandisit olan 215 hastanın verileri ile yine aynı şikayetlerle acil servisimize başvurup yapılan incelemeleri sonucunda renal kolik tanısı konan 200 hastanın verileri geriye dönük olarak yeniden değerlendirildi. Kontrol grubu olarak dâhiliye polikliniğine herhangi bir şikayeti olmayıp, sadece kan sayımı yaptırmak için başvuran 6 I hastanın verileri gene geriye dönük olarak değerlendirmeye alındı. Olguların acil servise geliş anında alınan WBC, RDW, Hb, MCV, MPV, nötrofil, lenfosit, NLR ve PLR değerleri incelenmiş olup, $\mathrm{P} \leq 0.05$ istatistiksel olarak anlamlı kabul edildi. Her bir grup kontrol grubuyla ve birbiriyle karşılaştıııldı. Karşılaştııılmalar yapılırken grupların dağılımına bakıldı, dağıımı normal olan gruplara parametrik, dağıııı normal olmayan gruplarda nonparametrik testler yapıldı.

BULGULAR: Akut apandisit $(n=2 / 5)$ ve renal kolik $(n=200)$ grubunda; yaş, WBC, Hb, MCV, nötrofil, lenfosit, NLR ve PLR arasında istatistiksel olarak anlamlı değişiklik olduğu, akut apandisit $(n=215)$ ve kontrol grubunda; yaş, WBC, Hb, RDW, MPV, nötrofil, lenfosit NLR ve PLR arasında istatistiksel anlamlı fark olduğu ve yine renal kolik ve kontrol grubunda; yaş, WBC, RDW, MPV, nötrofil ve NLR arasında istatistiksel fark olduğu görüldü. Hastalara ROC curve analizi yapıldığında WBC, nötrofil, NLR ve PLR'nin AUC altında kalan alanları sırasıyla 0.896, 0.916, 0.888 ve 0.725 olarak tespit edildi.

TARTIŞMA: WBC, RDW, MPV, nötrofil ve NLR'nin renal kolik ile herhangi bir rahatsızıı̆ı olmayan hastaların ayırımında ve WBC, Hb, RDW, MPV, nötrofil, lenfosit, NLR ve PLR'nin akut apandist hastalarının herhangi bir rahatsızığı olmayan hastalardan ayırımında, daha da önemlisi WBC, Hb, nötrofil, lenfosit, PLR ve NLR'nin acil servislerde karın ağıısı ile başvuran hastalarda akut apandisit ile renal kolik ayırımında kullanışlı bir parametre olabileceğini düşünmekteyiz.

Anahtar sözcükler: Akut apandisit; nötrofil/lenfosit oranı; renal kolik.

Ulus Travma Acil Cerrahi Derg 2016;22(1):17-22 doi: 10.5505/tjtes.2015.69488 